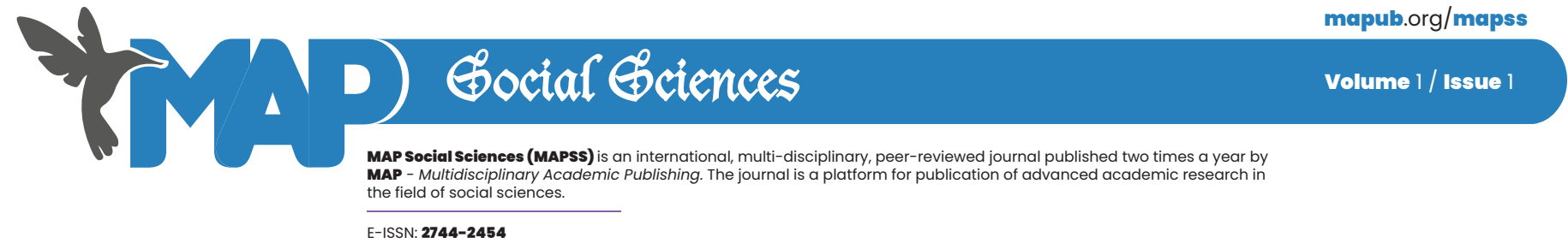

ORIGINAL RESEARCH PAPER

\title{
THE ROLE OF READING IN ENGLISH LANGUAGE CLASSROOMS
}

\author{
Aldiana Laličič́, Vildana Dubravac ${ }^{2}$ (1) \\ International Burch University, Sarajevo, Bosnia and Herzegovina \\ ${ }^{2}$ International Burch University, Sarajevo, Bosnia and Herzegovina
}

Correspondence concerning this article should be addressed to Aldiana Laličić, International Burch University, Sarajevo, Bosnia and Herzegovina. E-mail: aldiana.lalicic@stu.ibu.edu.ba and Vildana Dubravac, International Burch University, Sarajevo, Bosnia and Herzegovina. E-mail: vildana.dubravac@ibu.edu.ba

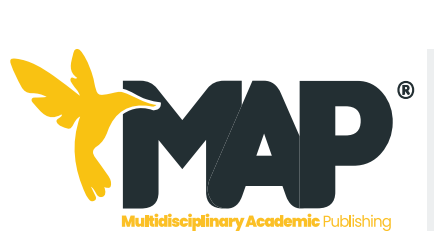

MAP SOCIAL SCIENCES

Volume 1/ Issue 1

ISSN: 2744-2454/ (c) 2021 The Authors. Published by MAP - Multidisciplinary

Academic Publishing.

Article Submitted: 28 July 202 Article Accepted: 15 August 202 Article Published: 03 September 202

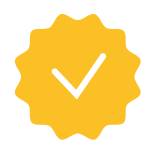

Publisher's Note: MAP stays neutral with regard to jurisdictional claims in published maps and institutional affiliations.

\section{ABSTRACT}

Being able to read well is crucially important for language learners. Successful performance at elementary and high school level, as well as on higher levels of academic education, is partly dependent on the ability to read. It is believed that good learners are those who are proficient in reading. However, building such a connection between a reader and the written information is complex for both English as a second language (ESL) and English as a foreign language (EFL) students, and requires the application of various reading strategies. The present study aimed to investigate EFL Bosnian learners' awareness of the use of various reading strategies. Furthermore, the study investigated students' reading habits, favorite reading materials, and the purpose of reading. It was conducted among fifty-seven ninth grade elementary school students. The findings proved that these students are aware of the importance of reading and development of reading skills, as well as of the importance of using appropriate reading strategies in order to be proficient readers and eventually to be more successful in the overall process of learning.

Keywords: reading, reading comprehension, reading strategies, reading habits, reading interests, language learning 


\section{Gocial Geiences \\ by MAP - Multidisciplinary Academic Publishing \\ THE ROLE OF READING IN ENGLISH LANGUAGE CLASSROOMS \\ Aldiana Laličić and Vildana Dubravac}

\section{Introduction}

In the process of acquiring a new language reading is considered an important part of the learning process (Akabuike \& Asika, 2012; Carter et al, 2010; Nel, Dreyer \& Kopper 2004; Floris \& Dvina, 2015; Palani, 2012; Pretorius, 2000; Tien, 2015). As a means of seeking knowledge, information or entertainment through the written words (Rwanda Book Development Initiative, 2011), the activity of reading, which starts with the beginning of school age and continues throughout students' lifetime, is the basic tool of learning. Actually, the ability to read is acknowledged as the most stable and durable of the second-language (L2) skills (Bernhardt, 1991). Krashen (2004) stated that spending much time on reading is more fruitful and beneficial for students than the time spent on teaching or learning vocabulary. He explained that spending time on reading motivates students more than spending time on retelling texts or learning new words by rote memorization. Palani $(2012$, p. 91) stated that "effective reading is the most important avenue of effective learning as the achievement of academic success requires successful reading". It helps learners develop other related skills such as grammar, vocabulary and writing (Koch, 1974). Thus, being a good reader is not a luxury in the 21st century, but a necessary life skill. In fact, it can be argued that reading is the essence of all formal education as "literacy in academic settings exists within the content of a massive amount of print information" (Grabe, 1991, p. 89) and students primarily access this information through reading.

However, understanding of the text cannot be acquired automatically by ESL/ EFL learners, but gradually developed using reading strategies (Bećirović, Brdarević-Čeljo \& Sinanović, 2017). They should be introduced at the very early stages of language learning, eventually leading to the development of independent and successful learners (Anderson, 1985; Afflerbach et al, 2008: Chamot, 2005; Oxford, 1990; Paris \& Jacobs, 1984; Pressley \& Afflerbach, 1995). Reading strategies are defined as an action or series of actions employed in order to construct meaning (Garner, 1987). In other words, they present learning techniques, behaviors, problem-solving or study skills which make learning more effective and efficient (Oxford \& Crookall, 1989). One significant type of reading strategies are metacognitive reading strategies, i.e. "intentional, carefully planned techniques by which learners monitor or manage their reading" (Sheorey \&
Mokhtari 2001, 436), further classified into global referring to reading methods used intentionally and unintentionally by readers to monitor reading (e.g. previewing, predicting, skimming, and scanning the text), problem solving entailing methods and actions used by readers to facilitate and better process reading the difficult text (e.g. include guessing the meaning of words, visualizing the reading materials, adjusting reading pace, and reading slowly) and support strategies used to help readers increase their comprehension of the text (e.g. taking notes while reading, paraphrasing the text, using related materials, asking questions, summarizing) (Mokhtari \& Reichard, 2002). As such, strategies are an instrument that allows learners to become self-directed, and they bring about better self-confidence, which contributes to more effective learning and enhancement of communicative competence (Oxford, 1990).

Exactly effective learning and developed communicative competence is what EFL learners strive to achieve worldwide, including Bosnia and Herzegovina $(\mathrm{B} \& \mathrm{H})$ (Dedović-Atilla \& Dubravac, 2017; Bećirović, Brdarević-Čeljo, \& Dubravac, 2018; Dubravac, 2016; Dubravac \& Latić, 2019; Dubravac \& Skopljak, 2020; Skopljak \& Dubravac, 2019; Dubravac, Brdarević-Čeljo, \& Bećirović, 2018; Tankosić \& Dubravac, 2016), English becoming necessary in order to meet different academic and job requirements, but also in terms of everyday life activities. In order to reach the above-mentioned requirements, it is necessary to emphasize the importance of reading strategies since their application leads to better academic and overall outcomes. Therefore, the current study aimed to explore students' awareness of metacognitive reading strategies among the Bosnian EFL ninth-grade elementary school students. In order to provide further insight into the issue in this rather unexplored EFL learning context, apart from reading strategies, the present study also investigated students' reading habits and interests, the frequency of reading, favorite reading materials and the purpose of reading. The results are expected to give educators reliable and helpful guidelines for organizing EFL classes, in particular those devoted to the development of reading skills.

\section{Literature review}

There are numerous studies investigating the role and significance of reading (e.g. Bećirović, Brdarević-Čeljo, \& Dubravac, 2018; Chege, 2012; 


\section{Gocial Geiences \\ by MAP - Multidisciplinary Academic Publishing \\ THE ROLE OF READING IN ENGLISH LANGUAGE CLASSROOMS \\ Aldiana Laličić and Vildana Dubravac}

Grimm, 2008; Keskin, 2013; Koda, 2007; Lerkkanen et al., 2005; Snow, 2002) which have revealed that learners who read effectively and use reading strategies are more proficient and achieve better academic results. Reading improves learners' spelling abilities and enriches their vocabulary storage (Carson, 2000; Kolawole, 2009), it facilitates the development of literacy skills that everyone needs for effective communication in different contexts. Although the importance of reading in terms of L2 knowledge development has been recognized (Aharony \& Bar-llan, 2018; Bouchamma et al., 2013; Cahyaningati \& Lestari, 2018; Eutsler \& Trotter, 2020; Hussain \& Munshi, 2011; Shonfeld \& Meishar-Tal, 2016), it still poses a challenge to many language learners. It is believed that students read not because they want to read, but because they have to read. Students perceive reading as a task that they have to undertake in order to excel academically. Interestingly, Kaur and Thivagarajah (1999) revealed that Malaysian students preferred to watch television and videos compared to reading for pleasure and as a result they read very little. Likewise, Yilmaz (2000) discovered that the majority of the students $(77.8 \%)$ do not possess any reading habits, wherein $(8.5 \%)$, which is the smallest percentage are heavy readers. Hastings and Henry (2006) in Loan (2012) observed that more than half of the students, i.e. (56\%), spend less than half an hour a day on reading and (13\%) are non-readers. Also, the downward trend of reading habits of college students was witnessed in United States of America by research carried out by National Endowment for the Arts (NEA) in 2008, when it was (51.7\%) compared to 1982 when it was (59.8\%). Therefore, students' reading preferences should be widely investigated to find a proper way of motivating them to read more.

In fact, Maro, Gusdian and Safitri (2020) conducted a study among 35 third semester students of the English Language Education Department, and identified several benefits of taking into account student's own preference in reading, namely easier comprehension of the content of the reading material; greater interest in reading; broader knowledge, and greater focus on the text. Their findings showed that novels are most preferred as their reading material (54.2\%). When it comes to the preferred genre $31.4 \%$ preferred fiction. A similar study was conducted by Johari et al. (2013) in the context of Malaysia. The findings indicated that students read to gain information and knowledge, though many chose reading as a hobby as their last choice in explaining their motives of reading.
Besides, they preferred non-academic reading materials, mainly lighter forms reading materials such as comics, story books and magazines. Another research by Bataineh and Al-Barakat (2005) investigated students' reading interests, the source of reading materials, and students' attitude toward reading. They found students' top preference are stories and picture books/magazines.

With the development of new technology and different kinds of media, electronic materials have become of great importance. However, there are research studies which have demonstrated that the experience of reading e-books is not equivalent to reading textbooks. Thus, Woody, Daniel and Baker (2010) tried to examine factors influencing preference for e-books as well as reported use of e-book content. Their findings revealed that students did not prefer e-books over textbooks regardless of their gender. No significant correlations existed between the number of e-books previously used and overall preference of e-books: Participants who had previously used an e-book still preferred print texts for learning. Despite the ability to easily access content through e-books via hyperlinks and other features, students were more likely to use print books than e-books. Chaudhry and Al-Adwani (2019) conducted a questionnaire-based survey on students' reading practices, in the English Department of the College of Basic Education, in Kuwait among 410 participants. It was found that students read mainly for entertainment, and reading did not appear to be a popular activity among students. Fiction, fashion, and best sellers were the three main types of reading, indicating that academic reading was not a priority. Only a small proportion of students used e-books, although they perceived e-books very useful because of their portability and ability to store more information. Actually, many researchers pointed out that younger users seem to prefer e-books to print-based learning resources, that e-book capabilities will continually improve, and that their costs will likely decrease in the future (Chang \& Ley, 2006; Li Liew, Foo, \& Chennupati, 2000; Temple, Kemp, \& Benson, 2006), contributing to their popularity. However, it seems that students enjoy much more reading other material available online. For instance, Huang, Capps, Blacklock, and Garza (2014) in their study pointed out that college students were reading materials from social media sites far more than from books, and in particular about twice as much material from social media sites as from leisure books. They noted that books for pleasure were being supplanted by Facebook 


\section{Gocial Geciences \\ by MAP - Multidisciplinary Academic Publishing}

THE ROLE OF READING IN ENGLISH LANGUAGE CLASSROOMS

Aldiana Laličić and Vildana Dubravac

and Twitter posts. We indeed witness immense popularity of social media among our students, particularly those younger ones.

It has been confirmed that reading preferences indeed differ with regard to age levels. Mellon (1990) surveyed the leisure reading choices of rural teenagers and found that their reasons for leisure reading were for entertainment and for acquiring information. Magazines and newspapers were found to be the most preferred reading materials of teenagers. It was also shown that informational reading was the main purpose for adult reading and their most popular books were: adventure, crime, social problems, novels, politics, and sports in ranking sequence. Platt (1986) reviewed several selected studies on reading preferences of adolescents, and concluded that adolescents read extensively books, periodicals, and newspapers. Graduate and undergraduate students' reading behaviors slightly vary. Hall (1989) examined 285 freshmen at a large southern urban university. Over $70 \%$ of all students favored reading magazines and newspapers most and novels least, and half of the students read the sports, entertainment and front-page sections of the newspaper regularly. In addition, graduate ESL students spent more time reading academic materials than did their undergraduate counterparts (Mokhtari \& Sheorey, 1994).

However, whatever kind of material is read, the process will be more fruitful if suitable strategies are applied. In this context, the significance of the metacognitive strategies cannot be neglected (Grabe \& Stoller, 2002; Kolic-Vehovec, 2006; O'Malley \& Chamot, 1990; Pazzaglia, De Beni \& Cristiante, 1994; Snow, 2002; Young \& Fry, 2008). Generally, EFL learners seem to demonstrate moderate to high awareness of reading strategies, while they tend to resort to problem solving strategies most, followed by global and support strategies (Anderson, 2002; Malcolm, 2009; Mokhtari \& Reichard, 2004; Zare \& Maftoon, 2014). Similarly, investigating the metacognitive reading strategies used by undergraduate students while reading academic texts, Rajab, Rahman, Wahab, Nor, Zakaria and Rajim (2017) found out that when students have difficulties in comprehending academic texts they tend to use more problem-solving reading strategies than global or support reading strategies. The findings indicated that students are not focusing on knowing the most effective strategies, but rather on how to use strategies effectively and appropriately.

When it comes to the context of the present study, there have been some studies conducted in order to investigate reading strategy use by Bosnian EFL learners (Bećirović, Brdarević-Čeljo, \& Sinanović, 2017; Bećirović, Brdarević-Čeljo, \& Dubravac, 2018). In their study, Bećirović, Brdarević-Čeljo and Sinanović (2017) investigated the overall usage of different types of metacognitive reading strategies by non-native English language speakers at International Burch University. They used the Metacognitive Reading Strategies Questionnaire (MRSQ) and the research sample was composed of 140 university-level students studying in two different fields, namely the field of English Language and Literature and Management. The analysis revealed that gender, grade level and study field had a significant effect on the use of metacognitive reading strategies, whereas the effect of nationality on the overall use of metacognitive reading strategies as well as on both of their subtypes was insignificant. Furthemore, Bećirović, Brdarević-Čeljo and Dubravac (2018) conveyed a study among 228 students studying at three different universities in Bosnia and Herzegovina. The aims of the study were to find out how gender, nationality, and grade point average affect the frequency of the usage of different types of reading strategies among Bosnian university students. The analysis revealed moderate to high awareness of reading strategies, the problem-solving strategies being most frequently used. A three-way ANOVA showed a significant main effect of gender as well as a significant interaction effect of Nationality $\times$ Grade Point Average on The Survey of Reading Strategies questionnaire. Moreover, a three-way MANOVA revealed that gender had a significant main effect on the combined variables (global, support, and problem-solving reading strategies). Similarly, the interaction effect of Nationality $\times$ Grade Point Average was significant on the three combined variables, while the interaction effects of Grade Point Average $\times$ Gender and Grade Point Average $\times$ Nationality proved significant only on the Problem-Solving subscale. However, further research investigating the role of reading in general and reading strategies should be done in Bosnian EFL context in order to provide us with a deeper insight into the subject matter. It would certainly contribute to better understanding of the reading strategies and it would help learners and teachers to recognize the importance of their use in FL classrooms. Thus, for the purpose of the study the following four research questions were introduced:

1. What is the purpose of students' reading? 


\section{Goctar Gibiences \\ by MAP - Multidisciplinary Academic Publishing}

THE ROLE OF READING IN ENGLISH LANGUAGE CLASSROOMS

Aldiana Laličić and Vildana Dubravac

2. Which print sources do students prefer to read?

3. What are the students' reading habits?

4. Which metacognitive strategies do they use most frequently?

\section{Methodology}

\section{Participants}

The present study was carried out among students in elementary school in Sarajevo, B\&H. The research sample consisted of 57 ninth-graders, aged $14 / 15$. There were $33(57.90 \%)$ female and 24 (42.10\%) male participants. The participants voluntarily completed the questionnaire. Figure 1 shows that at the time of completing the questionnaire the most participants had been studying English for seven years, i.e., from the third grade, while some of them had been studying English for ten years probably because they had been attending some private preschool language courses.

Figure 1: The length of studying English

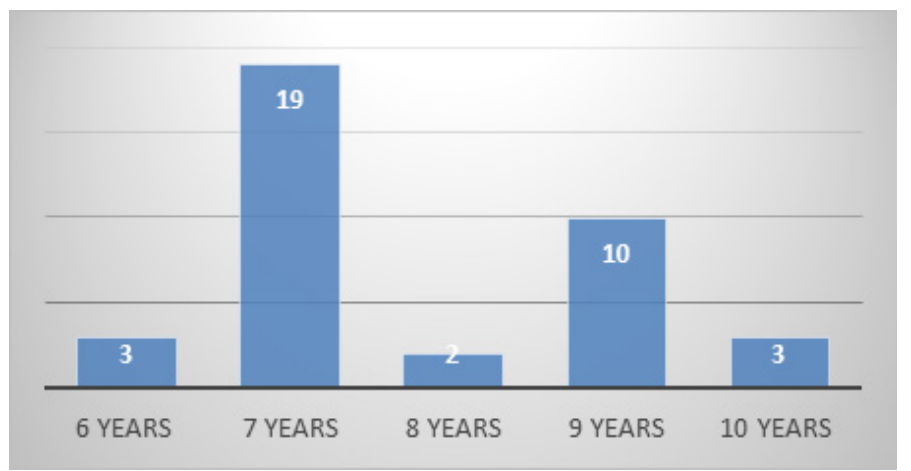

Figure 2 shows the students' last average English grade (ranging from 1 to 5). Taking into consideration that 1 is the lowest grade in Bosnian elementary schools and that 5 is the highest, we can see that $16 \%$ of the students had grade $5,24 \%$ of them grade $4,19 \%$ grade 3 . However, $25 \%$ of students had grade 2 and $16 \%$ of them had the lowest grade, the percent $(41 \%)$ with two lowest grades being an indicator that there is a lot of space for improvement and that teachers, educator, students and parents need to do their best in helping students to achieve better academic results and to analyze what could and should be changed and improved.
Figure 2: Students' last grade in English language course

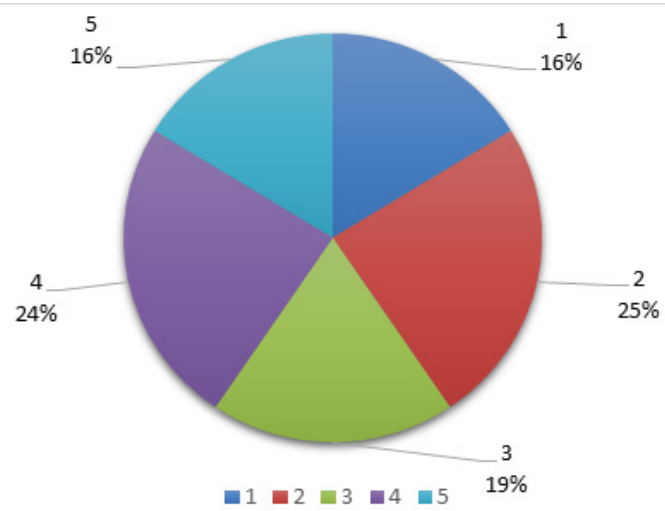

The next Figure shows the level of students' proficiency when it comes to four language skills. The greatest number of the students stated that they had excellent listening and then reading skills. The results indicate that the majority of students rated these four skills as good, which again implies that there is room for improvement.

Figure 3: Level of four language skills' proficiency

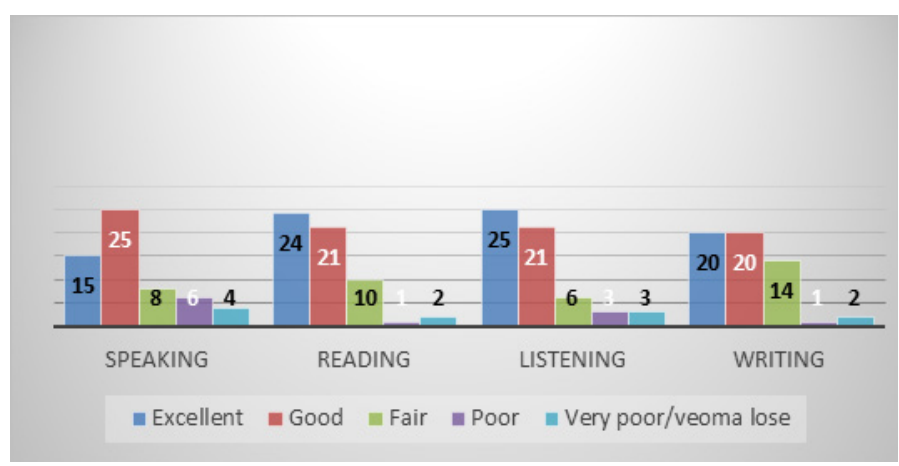

\section{Instrument and procedure}

The present study employed a quantitative research design. The instrument used to collect data was a questionnaire utilized by Maasum and Maarof (2012) but originally designed by Mokhtari and Reichard (2000) who developed Metacognitive Awareness of Reading Strategies Inventory (MARSI) in order to assess adolescents' and adult students' awareness and use of reading strategies while reading academic or school-related materials. The questionnaire comprised twenty-seven statements related to the students' approach to reading strategies. The students were asked to rate each statement on a 4 - point Likert Scale (e.g. I never use this strategy, I almost never use this strategy, I always use this strategy, I almost always use this strategy). 


\section{Goctar Gibiences \\ by MAP - Multidisciplinary Academic Publishing}

THE ROLE OF READING IN ENGLISH LANGUAGE CLASSROOMS

Aldiana Laličić and Vildana Dubravac

The statements in the questionnaire were categorized into three groups of strategies: Global strategies (e.g. I have a purpose in mind when I read), problem-solving strategies (I read slowly and carefully to make sure I understand what I am reading) and support strategies (When text becomes difficult, I read aloud to help me understand what I am reading). Besides using MARSI and in order to get an insight in students' achievement their last average English grade, ranging from 1 to 5 (1 being the lowest and 5 being the highest grade) was taken into consideration. The participants were also asked how long they had been learning English and to rate their level of four language skills proficiency. Moreover, they were asked to answer questions concerning the purpose of reading, what types of reading materials they use, their reading habits and interests in reading. Before the questionnaire was distributed to the students, an informed consent from the school's administration was obtained. The students were guaranteed anonymity and confidentiality and they had the opportunity not to be part of the research if they did not feel comfortable. The instrument was administered during a regular class period. To make sure that all students understood the questions and statements, the questionnaire was translated into Bosnian and they were given all the necessary information on how to fulfill the questionnaire. They were also ensured that their responses would not affect their grades. The participants were also asked to read each statement carefully and to complete the questionnaire as honestly as possible, since there were no right or wrong answers.

\section{Results}

According to the results presented in Figure 4, $30(52.63 \%)$ students strongly agree that they read to improve their communicative skills, and the same number of students $(52.63 \%)$ agree that they read for learning purposes, exams and to complete the assignments. Since these are elementary level students and their main goal is to get a better grade, reading is mostly related to school and school tasks. However, more than 20 students (36.84\%) said that reading is their hobby and this result is not to be underestimated. What students strongly agreed upon is that improving their reading skills would help them to improve their communicative skills.
Figure 4: Purpose of reading in English

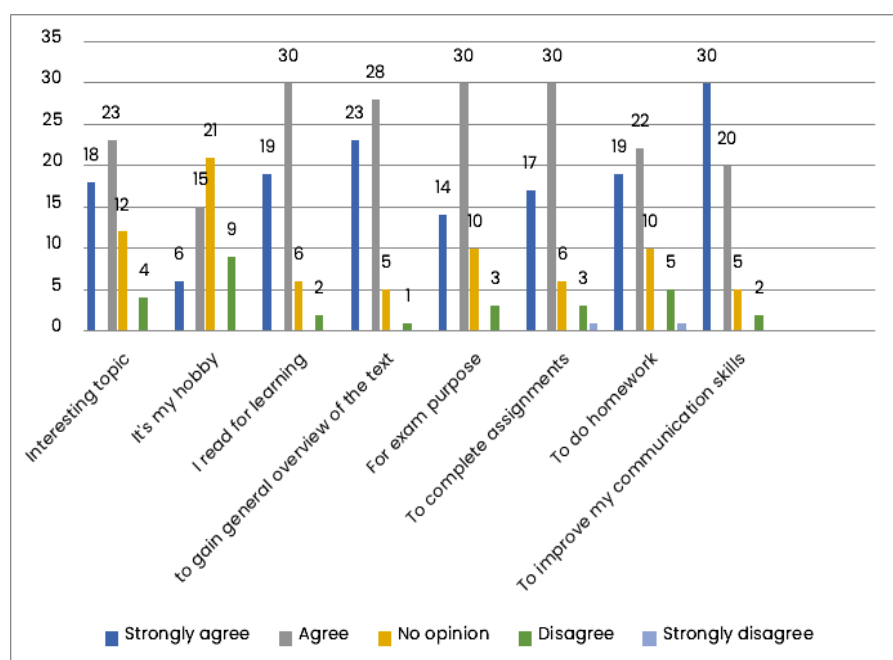

Various print sources preferred for reading are presented in Figure 5 as well as the frequency of students' reading. According to their answers, the students like to read encyclopedias (61.40\%), newspapers $(59.64 \%)$, magazines $(45.51 \%)$ and other print sources (43.85\%). However, the results show that books are the least preferred in comparison to all other print sources mentioned above, with only $36.84 \%$ of students who stated they prefer books. What else can be seen from the chart is that no matter which print source we refer to, students read them occasionally.

Figure 5: The use of various print sources.

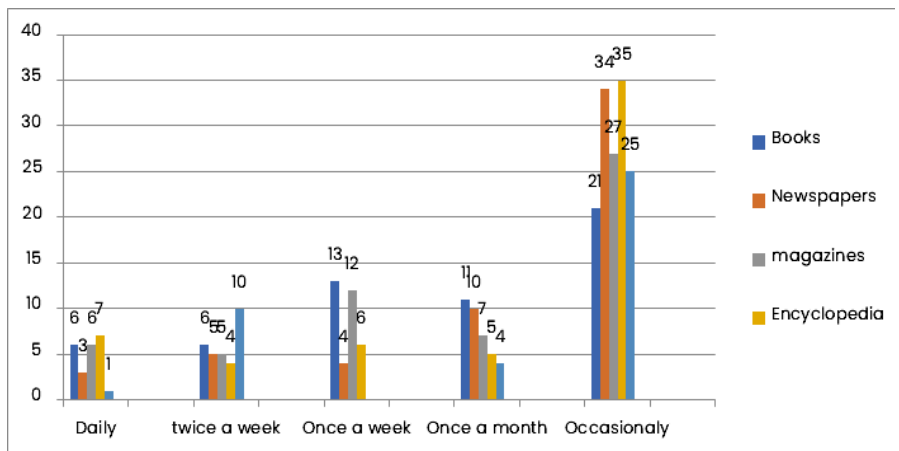

When it comes to students' reading habits, the results presented in Figure 6 show that elementary students' reading habits are quite good and as it can be seen the majority of students, 28 of them $(49.12 \%)$ read every day and only 2 students stated that they read in English only once in a month. 


\section{Goctar Gibiences \\ by MAP - Multidisciplinary Academic Publishing}

THE ROLE OF READING IN ENGLISH LANGUAGE CLASSROOMS

Aldiana Laličić and Vildana Dubravac

Figure 6: Students' reading habits

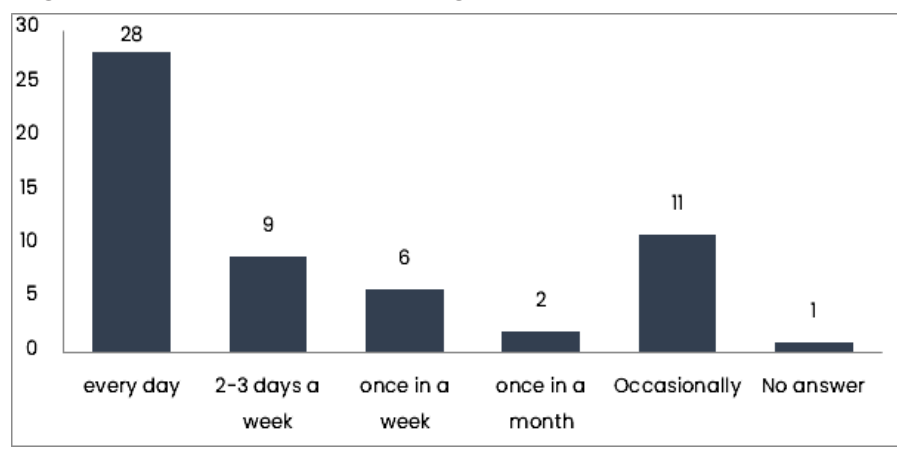

The last part of the questionnaire consisted of 27 statements referring to students' opinion about different metacognitive strategies used in improving their reading skills. The results are shown in percentages. The results on metacognitive strategies suggest that students are fully aware of them and that they use them regularly while reading. When considering subtypes of reading strategies, namely global, support and problem-solving reading strategies, the following results were obtained: students use global reading strategies and $40.35 \%$ use strategies two, four and ten, followed by strategies six and seven. Regarding global metacognitive reading strategies, it could be noticed that students do not prefer strategy number five, they do not use this strategy at all $(26.32 \%)$ or almost never (38.60\%). Referring to support metacognitive reading strategies, students prefer strategy number seven $(40.35 \%)$, followed by strategies six and one. However, the majority of students stated that they never $(35.09 \%)$ or almost never $(26.32 \%)$ use strategy number five. Finally, we have problem-solving strategies, where we can see that students prefer strategies number one $(43.86 \%)$ and $3(40.35 \%)$.

\section{Discussion}

The study aimed at exploring the role of reading among $9^{\text {th }}$ grade students in elementary school in B\&H. The results showed that most students have positive reading attitudes and very good reading habits. Moreover, students use metacognitive reading strategies in the process of learning, and it could be somewhat surprising that students use all three subtypes of metacognitive reading strategies almost equally.

In terms of the major purpose of reading, $52.63 \%$ students strongly agree that they read to improve their communicative skills. This is in line with the studies conducted by Grabe and Stroller (2011), Carson (2000), and Kolawole (2009). However, the same number of students agreed that they also read for learning purposes, exams and to complete the assignments; i.e., for better academic results and achievements which is aligned with the results reported by Bright and McGregor (1978), Grim (2008), Hijazi (2018), Keskin, (2013), Lerkkanen, et.al (2005), Reed, Petscher and Truckenmiller (2016), Tsai et al. (2001), and Yildiz (2013). Thus, students seem to be aware of a twofold importance of learning English, namely the importance visible in academic success, but also the importance visible in the use of English not only within the classes, but outside of them as well, where its strong presence has been acknowledged (Dedović-Atilla \& Dubravac, 2017; Bećirović, Brdarević-Čeljo, \& Dubravac, 2018; Dubravac, 2016; Dubravac, Brdarević-Čeljo, \& Bećirović, 2018; Dubravac \& Latić, 2019; Dubravac \& Skopljak, 2020; Skopljak \& Dubravac, 2019)

Table 1. The participants' responses regarding the use of specific reading strategies

\begin{tabular}{|l|c|c|c|c|}
\hline $\begin{array}{l}\text { METACOGNITIVE READING STRAT- } \\
\text { EGIES }\end{array}$ & $\begin{array}{c}\text { 1. I never use this } \\
\text { strategy }\end{array}$ & $\begin{array}{c}\text { 2. I almost never use } \\
\text { this strategy }\end{array}$ & $\begin{array}{c}\text { 3. I always use this } \\
\text { strategy }\end{array}$ & $\begin{array}{c}\text { 4. I almost always } \\
\text { use his strategy }\end{array}$ \\
\hline GLOBAL READING STRATEGIES & 7.02 & 19.30 & 38.60 & 35.09 \\
\hline $\begin{array}{l}\text { l.I have a purpose in mind when I } \\
\text { read. }\end{array}$ & 7.02 & 19.30 & 40.35 & 33.33 \\
\hline $\begin{array}{l}\text { 2. I think about what I know to help } \\
\text { me understand what I read. }\end{array}$ & 8.77 & 28.07 & 29.82 & 33.33 \\
\hline $\begin{array}{l}\text { 3. I take an overall view of the } \\
\text { text to see what it is about before } \\
\text { reading }\end{array}$ & & & \\
\hline
\end{tabular}




\section{Gocial Giciences \\ by MAP - Multidisciplinary Academic Publishing}

THE ROLE OF READING IN ENGLISH LANGUAGE CLASSROOMS

Aldiana Laličić and Vildana Dubravac

\begin{tabular}{|c|c|c|c|c|}
\hline $\begin{array}{l}\text { 4. I think about whether the content } \\
\text { of the text fits my reading purpose. }\end{array}$ & 14.04 & 22.81 & 40.35 & 22.81 \\
\hline $\begin{array}{l}\text { 5. I review the text first by noting } \\
\text { its characteristics like length and } \\
\text { organization. }\end{array}$ & 26.32 & 38.60 & 14.04 & 21.05 \\
\hline $\begin{array}{l}\text { 6. When reading, I decide what to } \\
\text { read closely and what to ignore. }\end{array}$ & 12.28 & 28.07 & 38.60 & 21.05 \\
\hline $\begin{array}{l}\text { 7. I use tables, figures, and pictures } \\
\text { in text to increase my understand- } \\
\text { ing. }\end{array}$ & 10.53 & 28.07 & 38.60 & 22.81 \\
\hline $\begin{array}{l}\text { 8. I use context clues to help me } \\
\text { better understand what I am read- } \\
\text { ing. }\end{array}$ & 17.54 & 35.09 & 28.07 & 19.30 \\
\hline $\begin{array}{l}9.1 \text { use typographical features like } \\
\text { bold face and italics to identify key } \\
\text { information. }\end{array}$ & 31.58 & 29.82 & 22.81 & 15.79 \\
\hline $\begin{array}{l}\text { 10. I critically analyze and evaluate } \\
\text { the information presented in the } \\
\text { text. }\end{array}$ & 19.30 & 22.81 & 40.35 & 17.54 \\
\hline $\begin{array}{l}11 . \text { I check my understanding when I } \\
\text { come across new information. }\end{array}$ & 10.53 & 31.58 & 31.58 & 26.32 \\
\hline \multicolumn{5}{|l|}{ SUPPORT READING STRATEGIES } \\
\hline $\begin{array}{l}\text { 1. When text becomes difficult, I } \\
\text { re-read it to increase my under- } \\
\text { standing. }\end{array}$ & 12.28 & 22.81 & 35.09 & 29.82 \\
\hline $\begin{array}{l}\text { 2. I take notes while reading to help } \\
\text { me understand what I read. }\end{array}$ & 24.56 & 22.81 & 29.82 & 22.81 \\
\hline $\begin{array}{l}\text { 3. When text becomes difficult, I } \\
\text { read aloud to help me understand } \\
\text { what I read. }\end{array}$ & 22.81 & 22.81 & 28.07 & 26.32 \\
\hline $\begin{array}{l}\text { 4. I underline or circle information in } \\
\text { the text to help me remember it. }\end{array}$ & 22.81 & 22.81 & 35.09 & 19.30 \\
\hline $\begin{array}{l}\text { 5. I use reference materials (e.g. } \\
\text { dictionary) to help me understand } \\
\text { what I read }\end{array}$ & 35.09 & 26.32 & 21.05 & 17.54 \\
\hline $\begin{array}{l}\text { 6. When text becomes difficult, I } \\
\text { pay closer attention to what I am } \\
\text { reading }\end{array}$ & 10.53 & 17.54 & 36.84 & 22.81 \\
\hline $\begin{array}{l}\text { 7. When reading, I translate from } \\
\text { English into my native language }\end{array}$ & 12.28 & 14.04 & 40.35 & 33.33 \\
\hline $\begin{array}{l}\text { 8. When reading, I think about } \\
\text { information in both English and my } \\
\text { mother tongue }\end{array}$ & 12.28 & 28.07 & 29.82 & 29.82 \\
\hline
\end{tabular}


by MAP - Multidisciplinary Academic Publishing

THE ROLE OF READING IN ENGLISH LANGUAGE CLASSROOMS

Aldiana Laličić and Vildana Dubravac

\begin{tabular}{|c|c|c|c|c|}
\hline \multicolumn{5}{|c|}{ PROBLEM-SOLVING READING STRATEGIES } \\
\hline $\begin{array}{l}1 . I \text { read slowly and carefully to } \\
\text { make sure I understand what I am } \\
\text { reading }\end{array}$ & 8.77 & 21.05 & 43.86 & 26.32 \\
\hline $\begin{array}{l}\text { 2. I try to get back on track when I } \\
\text { lose concentration }\end{array}$ & 10.53 & 21.05 & 36.84 & 31.58 \\
\hline $\begin{array}{l}\text { 3. I adjust my reading speed ac- } \\
\text { cording to what I am reading }\end{array}$ & 15.79 & 17.54 & 40.35 & 26.32 \\
\hline $\begin{array}{l}\text { 4. I stop from time to time and think } \\
\text { about what I am reading }\end{array}$ & 12.28 & 22.81 & 38.60 & 26.32 \\
\hline $\begin{array}{l}5 . \text { I try to picture or visualize infor- } \\
\text { mation to help me remember what } \\
\text { I read }\end{array}$ & 22.81 & 17.54 & 31.58 & 28.07 \\
\hline $\begin{array}{l}\text { 6. When I read, I guess the meaning } \\
\text { of unknown words or phrases }\end{array}$ & 14.04 & 17.54 & 36.84 & 31.58 \\
\hline
\end{tabular}

When it comes to the most common print source students prefer to use while reading, the findings revealed those are books. Although the results showed that students read various print materials, the highest percentage of them stated that they preferred encyclopedias, followed by newspapers and magazines. Books are the least preferred reading materials for the participants, which is similar to the results of other studies (Bataineh \& Al - Barakat, 2005; Johari, Tom, Morni \& Sahari, 2013). In other words, students prefer shorter texts, magazine and newspaper articles, encyclopedia entries over longer texts presented in books. One way to improve this is to make books more attractive to this population, and that might be done through e-book. In fact, many researchers pointed out that younger users seem to prefer e-books to print-based learning resources, that e-book capabilities will continually improve, and that their costs will likely decrease in the future (Chang \& Ley, 2006; Li Liew, Foo, \& Chennupati, 2000; Temple, Kemp, \& Benson, 2006). Hernon et al. (2007) pointed out that e-book reading in higher education has numerous advantages, particularly the access it affords to a wide variety of reading sources and to up-to-date reading material. Although students are nowadays presented with various types of reading materials whether print or internet materials, some students still do not have developed reading skills or strategies, and the reason is the lack of good reading habits and interests. It is important for all those involved in the educational process to continue working and improving students' reading habits, since reading is currently recognized as one of the most significant sources of input for L2 and FL acquisition
(Dupuy, Tse \& Cook, 1996; Kim \& Krashen, 1997; Gove $\&$ Cvelich, 2010)

With reference to students reading habits, the outcomes of the study revealed that participants actually read quite often. This is not surprising since they need to read in order to fulfil their school duties. However, students nowadays, including the good ones, do not read for pleasure (Safiah, 1990). It is believed that students read not because they want to read, but because they have to read. Students perceive reading as a task that they have to undertake in order to achieve better academic results. This is an aspect that needs improvement. Parents and teachers can do much to promote reading for pleasure from an early age, and thus give in the children's hands a very useful tool for success in various domains of life. In addition to promoting reading for pleasure, we can help learners teaching them various reading strategies and emphasizing the importance of the awareness of their use.

In fact, the present study participant are generally aware of reading strategy use. Among global strategies they most often critically analyze the content, have a purpose while reading, rely on their pre-knowledge while reading, and think whether the content fits the purpose. However, the greatest number of the participants never or almost never rely on the following strategies: use context clues, review the text before reading it carefully, use typographical features to identify key information. Among support strategies the most common seems to be translation into $\mathrm{Ll}$, rereading the 


\section{Gocial Geiences \\ by MAP - Multidisciplinary Academic Publishing \\ THE ROLE OF READING IN ENGLISH LANGUAGE CLASSROOMS \\ Aldiana Laličić and Vildana Dubravac}

text, and paying closer attention to it. On the other hand, much can be done in terms of the following strategies: taking notes, reading aloud and using reference materials. In terms of problem-solving strategies, they most frequently resort to reading slowly and carefully, adjusting the reading speed, stopping from time to time to think about the content and guessing the meaning of unknown phrases. These tendences probably mirror the classroom practice of their teachers. Thus, teachers can do much to help their learners in developing other not so popular strategies incorporating their use in everyday practice. It is definitely worth the effort, as reading strategies can lead to a competent and independent reader who will be able to achieve better academic success (O'Malley \& Chamot, 1990).

\section{Conclusion}

The appropriate use of reading strategies helps students in improving their reading abilities, with a potential of leading to improvement in their overall English proficiency. We cannot avoid the fact that reading is a very complex process and that even today, with all the technological advancements in our everyday lives as well as in the education, some learners face difficulties with reading. The main reason is that students spend little time to improve their reading skills, then we have inappropriate reading strategies, reading materials and the classroom settings are also challenging issues. Teachers play an important role in teaching students reading strategies. There is no ideal strategy for all students and all English classes but reading activities should be arranged from basic to more complex ones as the learners gain their confidence in acquiring the English language.

There are some limitations to this study as for the number of the participants could have been larger in order to obtain more relevant data. The study was conducted only with elementary level students and for the future research high school and maybe university students should be involved as well. Teachers' points of view would be also of great importance.

\section{References}

Afflerbach, P., Pearson, P. D., \& Paris, S. G. (2008). Clarifying differences between reading skills and reading strategies. The reading teacher, 61(5), 364-373.
Aharony, N., \& Bar-llan, J. (2018). Students' academic reading preferences: An exploratory study. Journal of Librarianship and Information Science, 50(1), 3-13.

Akabuike, I. G., \& Asika, I. E. (2012). Reading habits of undergraduates and their academic performances: Issues and perspectives. African Research Review, 6(2), 246-257.

Anderson, N.J. (1985). Cognitive Psychology and Its Implications. New York.

Anderson, N. J. (2002). The Role of Metacognition in Second/Foreign Language Teaching and Learning. ERIC Digest. Washington DC: ERIC Clearinghouse on Languages and Linguistics.

Bataineh, R. F., \& Al-Barakat, A. A. (2005). The Reading Interests of Jordanian First-, Second and Third-Grade Pupils and the Obstacles Limiting these Interests. Journal of Educational \& Psychological Sciences, 6(03), 107-133.

Bećirović, S, Brdarević-Čeljo, A., \& Dubravac, V. (2018). The effects of nationality, gender, and GPA on the use of reading strategies among EFL university students. SAGE Open, 8(4), 1 -12. https://doi. org/10.1177/2158244018809286

Bećirović, S., Brdarević-Čeljo, A., \& Sinanović, J. (2017). The use of metacognitive reading strategies among students at international Burch university: A case study. European Journal of Contemporary Education, 6(4), 645-655.

Bernhardt, E. (1991). Reading development in a second language: Theoretical, empirical, and classroom perspectives. Norwoord, NJ: Ablex.

Bouchamma, Y., Poulin, V., Basque, M., \& Ruel, C. (2013). Impact of students' reading preferences on reading achievement. Creative Education, 4(08), 484.

Bright, J.A., \& McGregor, G.P. (1970). Teaching English as a second language. London: Longman

Cahyaningati, D. T., \& Lestari, L. A. (2018). The use of multimodal text in enhancing engineering students' reading skill. International Journal of Language Education, 2(2), 65-73. doi:10.26858/ijole. v2i2.6360 


\section{Gocial Geiences \\ by MAP - Multidisciplinary Academic Publishing \\ THE ROLE OF READING IN ENGLISH LANGUAGE CLASSROOMS \\ Aldiana Laličić and Vildana Dubravac}

Cantrell, S. C., Almasi, J. F., Carter, J. C., Rintamaa, M., \& Madden, A. (2010). The impact of a strategy-based intervention on the comprehension and strategy use of struggling adolescent readers. Journal of Educational Psychology, 102(2), 257.

Carson, J. \& Leki, I. (1993). Reading in the composition classroom: Second language perspective. Heinle \& Heinle, Boston.

Chamot, A. U. (2005). Language learning strategy instruction: Current issues and research. Annual Review of Applied Linguistics, 25, $112-130$

Chang, S. L., \& Ley, K. (2006). A learning strategy to compensate for cognitive overload in online learning: Learner use of printed online materials. Journal of Interactive Online Learning, 5(1), 104-117.

Chaudhry, A. S., \& Al-Adwani, A. (2019). Reading practices of EFL students: A survey of Kuwaiti college students. English language teaching, 12(5), 130-144.

Chege, E. W. (2012). Reading comprehension and its relationship with academic performance among standard eight pupils in rural Machakos (Unpublished Doctoral dissertation, Kenyatta University).

Dedović-Atilla, E., \& Dubravac, V. (2017). From EFL to ELF: The new kid on the block. Zbornik radova Islamskog pedagoškog fakulteta u Zenici 15, 257277.

Dubravac, V., \& Latić, E. (2019). The plasticity of students' language learning beliefs: The interplay of gender, grade and educational level. Journal of Language and Education, 5(4), 36-53. doi: https:// doi.org/10.17323/jle.2019.9732

Dubravac, V., \& Skopljak, N. (2020). Foreign and multilingual language play on social sites as an identity marker. Journal of Multicultural Discourses, 15(1), 61-79. doi: https://doi.org/10.1080/17447143.201 9.1701678

Dubravac, V. (2016). The impact of English on language use in the Bosnian press. In L. Buckingham (Ed.), The status of English in Bosnia and Herzegovina (pp. 203-227). Bristol, Buffalo: Multilingual Matters.
Dubravac, V., Brdarević-Čeljo, A., \& Bećirović, S. (2018). The English of Bosnia and Herzegovina. World Englishes, 37 (4), 635-652. doi: https://doi. org/10.1111/weng.12347

Dupuy, B., Tse, L., \& Cook, T. (1996). Bringing books into the classroom: First steps in turning college-level ESL students into readers. TESOL Journal, $5,10-15$.

Eutsler, L., \& Trotter, J. (2020). Print or iPad? Young Children's Text Type Shared Reading Preference and Behaviors in Comparison to Parent Predictions and At-home Practices. Literacy Research and Instruction, 59(4), 324-345.

Floris, F., \& Dvina, M. (2009). Study on the Reading Skills of EFL University Students. TEFLN Journal, 20(1), 37-471

Garner, R. (1987). Metacognition and reading comprehension. Norwood, NJ: Ablex Publishing.

Gove, A., \& Cvelich, P. (2010). Early reading: Igniting education for all: A report by the Early Grade Learning Community of Practice (Rev. ed.). $R e^{-}$ search Triangle Park, NC: RTI.

Grabe, W. (1991). Current developments in second language reading research. TESOL Quarter$l y, 25,375-406$.

Grabe, W., \& Stoller, F (2011). Teaching and Researching Reading. Longman/Pearson. https:// doi.org/10.1002/9781405198431.wbeal1174

Hernon, P., Hopper, R., Leach, M. R., Saunders, L. L., \& Zhang, J. (2007). E-book use by students: Undergraduates in economics, literature, and nursing. The Journal of Academic Librarianship, 33(1), 3-13.

Grim, F. (2008). Integrating Focus on Form in L2 Content-Enriched Instruction Lessons. Foreign Language Annals, 4l(2), 321-346.

Hall, W. S. (1989). Reading comprehension (Vol. 44, No. 2, p. 157). American Psychological Association.

Hastings, C., \& Henry, J. (2006). Reading is a closed book to today's children. Telegraph. 


\section{Gocial Geiences \\ by MAP - Multidisciplinary Academic Publishing \\ THE ROLE OF READING IN ENGLISH LANGUAGE CLASSROOMS \\ Aldiana Laličić and Vildana Dubravac}

Henk, W. A., Helfeldt, J. P., \& Platt, J. M. (1986) Developing reading fluency in learning disabled students. Teaching Exceptional Children, 18(3), 202206.

Hijazi, D. (2012). Difficulties Jordanian non-English major university students face while learning English as a foreign language: A student perspective. Journal of the College of Education, Aswan University, 26, 29-54.

Huang, S., Capps, M., Blacklock, J., \& Garza, M. (2014). Reading habits of college students in the United States. Reading Psychology, 35(5), 437-467.

Hussain, I., \& Munshi, P. (2011). Identifying reading preferences of secondary school students. Creative Education, 2(05), 429.

Johari, A., Tom, A. A., Morni, A., \& Sahari, S. H. (2013). Students' reading practices and environments. Indonesian Journal of Applied Linguistics, 3(1), 17-28.

Kaur, S., \& Thivagarajah, R. (1999). The Reading Habits of ELLS Students in University Science Malaysia. Universiti Sains Malaysia.

Keskin, H. K. (2013). Impacts of reading metacognitive strategies and reading attitudes on school success. International Journal of Academic Research, 5(5), 312-317.

Kim, H., \& Krashen, S. (1997). Why don't language acquirers take advantage of the power of reading. TESOL Journal, 6(3), 26-29.

Koch, R. E. (1974). Relationships between reading interests and reading comprehension among fourth-grade and sixth-grade students. University of Illinois at Urbana-Champaign.

Koda, K. (2005). Insights into second language reading: A cross-linguistic approach. Cambridge: Cambridge University Press

Kolawole, C. O. O. (2009). The state of reading in selected secondary schools in Oyo State, $\mathrm{Ni}-$ geria. An International Multi-Disciplinary Journal, 3(1), 388-398.
Kolić-Vehovec, S., \& Bajšanski, I. (2006). Metacognitive strategies and reading comprehension in elementary-school students. European Journal of Psychology of Education, 21(4), 439-451.

Krashen, S. (2004). The Power of Reading (2nd Ed.). Englewood, CO: Libraries Unlimited.

Lerkkanen, M. K., Rasku-Puttonen, H., Aunola, K., \& Nurmi, J. E. (2005). Mathematical performance predicts progress in reading comprehension among 7-year olds. European Journal of Psychology of Education (EJPE, Instituto Superior de Psicologia Aplicada), 20(2), 121-137.

Li Liew, C., Foo, S., \& Chennupati, K. R. (2000). A study of graduate student end-users' use and perception of electronic journals. Online Information Review, 24(4), 302-315.

Malcolm, D. (2009). Reading strategy awareness of Arabic-speaking medical students studying in English. System, 37(4), 640-651. https:// doi.org/10.1016/j.system.2009.09.008

Maro, R. K., Gusdian, R. I., \& Safitri, B. F. (2020). Investigating English language education students' reading preferences. English Review: Journal of English Education, 8(2), 323- 328. doi: 10.25134/erjee. v8i2.3029

Maasum, T., \& N. Maarof. 2012. “Empowering ESL Readers with Metacognitive Reading Strategies." Procedia-Social and Behavioral Sciences 69: 1250-1258. doi:10.1016/j. sbspro.2012.12.58.

Mellon, C. A. (1990). Leisure Reading Choices of Rural Teens. School Library Media Quarterly, 18(4), 223-28.

Mokhtari, K., \& Reichard, C. A. (2002). Assessing students' metacognitive awareness of reading strategies. Journal of educational psychology, 94(2), 249

Mokhtari, K., \& Sheorey, R. (2002). Measuring ESL Students' Awareness of Reading Strategies. Journal of Developmental Education, 25 (3), 2-10.

Nel, C., Dreyer, C., \& Klopper, M. (2004). An analysis of reading profiles of first-year students at Potchefstroom University: a cross-sectional study and a case study. South African Journal of Education, 24(1), 95-103. 


\section{Gocial Geiences \\ by MAP - Multidisciplinary Academic Publishing \\ THE ROLE OF READING IN ENGLISH LANGUAGE CLASSROOMS \\ Aldiana Laličić and Vildana Dubravac}

O'Malley, J. \& Chamot, A. (1990). Learning strategies in second language acquisition. New York: Cambridge University Press.

Oxford, R.L. (1990). Language learning strategies: What every teacher should know. Boston,MA: Heinle \& Heinle Publishers.

Oxford, R., \& Crookall, D. (1989). Research on language learning strategies: Methods, findings, and instructional issues. The modern language Journal, 73(4), 404-419.

Palani, K.K. (2012). Promising reading habits are creating literate society. International Reference Research Journal, 2(1), 91-98.

Paris, S. G., \& Jacobs, J. E. (1984). The benefits of informed instruction for children's reading awareness and comprehension skills. Child development, 2083-2093.

Pazzaglia, F., De Beni, R., \& Cristante, F. (1994). Prova di metacomprensione [Metacomprehension test]. Firenze, Italia: Organizzazioni Speciali.

Pressley, M., \& Afflerbach, P. (1995). Verbal protocols of reading: The nature of constructively responsive reading. Lawrence Erlbaum Associates, Inc.

Pretorius, E. J. (2000). Reading and the Unisa student: Is academic performance related to reading ability? Progressio, 22(2), 35-48.

Rajab, A., Rahman, H. A., Wahab, S. R. A., Nor, F. M., Zakaria, W. Z., \& Rajim, W. Z. (2017). Metacognitive reading strategies among undergraduates. International Journal of Information and Education Technology, 7(7), 548-551.

Reed, D. K., Petscher, Y., \& Truckenmiller, A. J. (2016). The contribution of general reading ability to science achievement. Reading Research Quarterly, 52(2), 253-266. doi: 10.1002/rrq.158

Rwanda Book Development Initiative. (2011). Importance and challenges of reading culture in Rwanda. https://www.newtimes.co.rw/section/ $\mathrm{read} / 83420$

Safiah O. (1990). Membaca: Satu PengenaIan. Kuala Lumpur: Berita Publishing Sdn. Bhd.
Shonfeld, M., \& Meishar-Tal, H. (2016). Writing and reading preferences for student learning in a paperless classroom. In Society for Information Technology \& Teacher Education International Conference (pp. 787-792). Association for the Advancement of Computing in Education (AACE).

Sheorey, R., \& Mokhtari, K. (2001). Differences in the metacognitive awareness of reading strategies among native and non-native readers. System, 29(4), 431-449.

Skopljak, N. \& Dubravac, V. (2019). The impact of English on the Bosnian language and the use of English words in Bosnian. HUM, 14 (22), 138156.

Snow, C. (2002). Reading for understanding: Toward an R\&D program in reading comprehension. Sanata Monica Rand Corporation.

Tankosić, A., \& Dubravac, V. (2016). The assessment of Bosnian EFL learners' knowledge by two different measures: test and writing assignment. ExELL, 4(1), 41-57. doi: https://doi.org/10.1515/ exell-2017-0006

Temple, N. J., Kemp, W. C., \& Benson, W. A. (2006). Computer technology and student preferences in a nutrition course. Open Learning: The Journal of Open, Distance and e-Learning, 21(1), 7177.

Tien, C. Y. (2015). A large-scale study on extensive reading program for non-English majors: Factors and attitudes. International Journal of Applied Linguistics and English Literature, 4(4), 46-54.

Tsai, J. L., Lee, C. Y., Tzeng, O. J., Hung, D. L., $\&$ Yen, N. S. (2004). Use of phonological codes for Chinese characters: Evidence from processing of parafoveal preview when reading sentences. Brain and language, 91(2), 235-244.

Woody, W. D., Daniel, D. B., \& Baker, C. A. (2010). E-books or textbooks: Students prefer textbooks. Computers \& education, 55(3), 945-948.

Yildiz, M. (2013) Adaptation of the motivation to read profile to Turkish. International Journal of Academic Research, Part B, 5(4), 196-199. 
by MAP - Multidisciplinary Academic Publishing

THE ROLE OF READING IN ENGLISH LANGUAGE CLASSROOMS

Aldiana Laličić and Vildana Dubravac

Yilmaz, B. (2000). Reading and library usage habits of the students whose mother tongue is Turkish in Vienna, Austria. Retrieved on July 2, 2021. from http://www.ifla.org/IV/ifla66/papers/084-152e.htm

Young, A., \& Fry, J. D. (2008). Metacognitive awareness and academic achievement in college students. Journal of the Scholarship of Teaching and Learning, 8(2), 1-10.

Zare. J., \& Maftoon, P. (2014). Reading strategy use and field of study: A mixed-methods study. Iranian Journal of Applied Language Studies, 7(1), 171-196 